\title{
Teat apex colonization with coagulase-negative Staphylococcus species before parturition: Distribution and species-specific risk factors
}

\author{
A. De Visscher, ${ }^{* 1}$ S. Piepers, ${ }^{*}$ F. Haesebrouck, $\dagger$ and S. De Vliegher* \\ *M-team and Mastitis and Milk Quality Research Unit, Department of Reproduction, Obstetrics, and Herd Health, and \\ †Department of Pathology, Bacteriology, and Avian Diseases, Faculty of Veterinary Medicine, Ghent University, 9820 Merelbeke, Belgium
}

\begin{abstract}
Coagulase-negative staphylococci (CNS) are the main cause of bovine intramammary infections and are also abundantly present in extramammary habitats such as teat apices. Teat apex colonization (TAC) with CNS has already been explored in lactating dairy cows at the species level, whereas this is not true for dry cows and end-term heifers. Therefore, the aim of this observational study was to describe CNS TAC in nonlactating dairy cows and end-term heifers in Flemish dairy herds and to identify associated risk factors at the herd, cow, and quarter level. All CNS were molecularly identified to the species level using transfer RNA intergenic spacer PCR (tDNA-PCR) and sequencing of the 16S rRNA gene, allowing for species-specific statistical analyses using multivariable, multilevel logistic regression. Staphylococcus devriesei, Staphylococcus chromogenes, Staphylococcus haemolyticus, and Staphylococcus equorum were the most frequently isolated species. Staphylococcus chromogenes was the sole species colonizing teat apices of cows and heifers in all herds, whereas large between-herd differences were observed for the other species. Teat apices of red and white Holstein Friesians, of quarters dried off without an internal teat sealer, and swabbed in months with lower precipitation and higher ambient temperature were significantly more likely to be colonized by $S$. devriesei. Slightly dirty teat apices and teat apices swabbed in months with lower precipitation had higher odds of being colonized by $S$. chromogenes, whereas teat apices sampled in months with lower precipitation and higher ambient temperature were more likely to be colonized by $S$. haemolyticus. Dirty teat apices and teat apices swabbed in months with lower ambient temperature in combination with low precipitation had higher odds of being colonized by $S$. equorum. Diverse factors explaining CNS TAC, yet mostly related to humidity, ambient
\end{abstract}

Received August 28, 2015

Accepted October 25, 2015 .

${ }^{1}$ Corresponding author: Anneleen.Devisscher@UGent.be temperature, and hygiene, substantiate differences in epidemiological behavior and ecology between species.

Key words: teat apex, coagulase-negative Staphylococcus species

\section{INTRODUCTION}

Besides being the most common cause of intramammary infections in dairy cows in many regions and countries (Vanderhaeghen et al., 2015), CNS are abundantly present in extramammary habitats such as sawdust and air (Piessens et al., 2011) and also colonize dairy cows' teat apices (Taponen et al., 2008; Braem et al., 2012; De Visscher et al., 2014). In fact, the majority of teat apices colonizing microbiota belong to the group of the CNS (Braem et al., 2013). Differences in ecological and epidemiological characteristics among bovine-associated CNS species have been revealed (Vanderhaeghen et al., 2015), yet many aspects remain undetermined. The presence of CNS on teat apices of lactating dairy cows and heifers has already been explored at the species level (Taponen et al., 2008; Braem et al., 2013; De Visscher et al., 2014; Vanderhaeghen et al., 2015) but little is known about CNS teat apex colonization (TAC) in dry cows and end-term heifers. A high prevalence of CNS colonized teat apices in pregnant dairy heifers before calving has been described (De Vliegher et al., 2003; Piepers et al., 2011), but those studies either solely concerned heifers, studied CNS as a group, or focused specifically on Staphylococcus chromogenes only using nonmolecular identification. Large observational studies describing the species distribution on teat apices in nonlactating dairy cows and end-term heifers and identifying factors associated with their presence are needed to add to our understanding of the role of CNS species in bovine udder health (Taponen et al., 2008; De Visscher et al., 2014; Vanderhaeghen et al., 2015). Although we have started to learn about the relation between CNS TAC and IMI and associations seem to be present (Leroy et al., 2015), potential protective aspects of TAC remain to be studied (Vanderhaeghen et al., 2014). 
Therefore, this study aimed to determine and to describe (1) the species-specific prevalence of CNS colonization of teat apices of dry cows and end-term heifers before calving; (2) the CNS distribution; (3) associated herd-, cow-, and quarter-level risk factors; and (4) the variance components of CNS TAC.

\section{MATERIALS AND METHODS}

\section{Herds and Cows}

Thirteen commercial Flemish dairy herds were included, all of them participating in the DHI program (CRV, Arnhem, the Netherlands), being a first selection criterion. Other inclusion criteria were no prepartum antibiotic treatment of heifers and the use of AI as accurate expected calving dates were demanded. The majority of farmers $(n=8)$ only housed dairy cattle, whereas the others also farmed pigs $(\mathrm{n}=1)$ or beef cattle $(\mathrm{n}=4)$. The DHI records and bulk milk quality data of the Milk Control Centre Flanders (Lier, Belgium) allowed for calculating the herd size and the bulk milk SCC, respectively, at the start of the sampling period in July 2012. The entire sampling period lasted until February 2013. Before the start of the study, an average of 57 cows and heifers were in lactation (range $=30-95)$ per herd (arithmetic mean of the 6 last testday samples). The geometric mean bulk milk SCC was 201,000 cells $/ \mathrm{mL}($ range $=79,000-310,000$ cells $/ \mathrm{mL})$. On 7 of the farms, dry cows were housed on concrete slatted floor with cubicles with mats $(\mathrm{n}=4)$, mattresses $(\mathrm{n}=2)$, or without bedding $(\mathrm{n}=1)$. The other 6 farms kept the dry cows on straw, either in a deep litter barn $(\mathrm{n}=5)$ or in deep litter boxes with a bottom layer of sand and a full concrete floor $(\mathrm{n}=1)$. Pregnant heifers were typically housed on a concrete slatted floor in cubicles $(\mathrm{n}=11)$ with mats $(\mathrm{n}=5)$, with mattresses $(\mathrm{n}=5)$, or without bedding $(\mathrm{n}=1)$. The other 2 farms housed the pregnant heifers either in a deep litter barn with straw $(\mathrm{n}=1)$ or in deep litter boxes with a bottom layer of sand and straw $(\mathrm{n}=1)$. On the majority of farms, dry cows and pregnant heifers $(\mathrm{n}=12$ and $\mathrm{n}=11$, respectively) were kept on pasture between May and September. Seven of the herds housed the dry cows separated from the lactating cows before calving, whereas in the majority of herds $(\mathrm{n}=10)$ the pregnant heifers were housed together with the lactating cows.

On each farm, 12 pregnant heifers and dry cows (total $\mathrm{n}=156$ ) were selected according to the proportion of lactating cows and heifers present in the herd at the start of the study, reflecting the parity distribution in the herd, resulting in a total of 53 pregnant heifers and 103 dry cows (range $=$ start of second lactation to start of tenth lactation). The majority of the selected animals were black and white Holstein Friesian (HF; $85 \%, \mathrm{n}=132$ ), and $15 \%$ were red and white HF (n $=24)$. Eighty-five percent $(\mathrm{n}=132)$ of the animals were supplemented with minerals and vitamins before parturition. On all farms, blanket dry cow treatment was applied using either cloxacillin benzathine ( $47 \%$ of the 103 dry cows, $\mathrm{n}=48$ cows) or cephalosporins with a broad or gram-positive spectrum $(40 \%, \mathrm{n}=41$ cows and $10 \%, \mathrm{n}=10$ cows, respectively). Dry cow treatment information was lacking for a few cows only $(3 \%$, $\mathrm{n}=3$ ) as these cows were purchased when dry. One cow did not receive antimicrobials at drying-off due to a sudden drop in milk production. Only a minority of the dry cows received an internal teat sealer $(39 \%$ of the 103 dry cows, $n=40$ ) at drying off. Iodine teat dip was applied to 38 dry cows and end-term heifers (24\%) before parturition.

\section{Samples and Data Collection}

To determine TAC before parturition, swabs of all teat apices of the 153 cows and heifers (total $n=624$ ) were collected $14 \mathrm{~d}$ before expected calving date. Visible soil and manure were first removed. Further, a dry cotton swab (Copan, Novolab, Belgium) was rotated gently on the teat apex as described by De Vliegher et al. (2003). Swabs were transported under cooled condition $\left(4^{\circ} \mathrm{C}\right)$ to the Mastitis and Milk Quality Research Lab (Faculty of Veterinary Medicine, Ghent University, Merelbeke, Belgium).

Several herd- and cow-level factors, potentially associated with CNS (species-specific) TAC, were either calculated based on DHI records or on data of the Milk Control Centre Flanders, or collected before the onset of the study via a questionnaire (Table 1). Other potential cow- and quarter-level factors were recorded at sampling (teat swabbing; Table 1).

\section{Laboratory Analyses}

All swabs were plated on mannitol salt agar (Oxoid, Erembodegem, Aalst, Belgium; one plate per swab; De Visscher et al., 2013). Plates were aerobically incubated at $37^{\circ} \mathrm{C}$ and examined after 24 and $48 \mathrm{~h}$. One colony of all phenotypically different colony types was picked up and subcultured on esculin blood agar (Oxoïd; one quadrant per isolate) to obtain pure cultures for subsequent analysis. All potential CNS isolates were stored at $-80^{\circ} \mathrm{C}$ or immediately identified to the species level using transfer RNA intergenic spacer PCR (tDNAPCR). If no identification could be obtained, sequencing of the 16S rRNA gene was performed (Supré et al., 2009). 
TEAT APEX COLONIZATION WITH COAGULASE-NEGATIVE STAPHYLOCOCCI

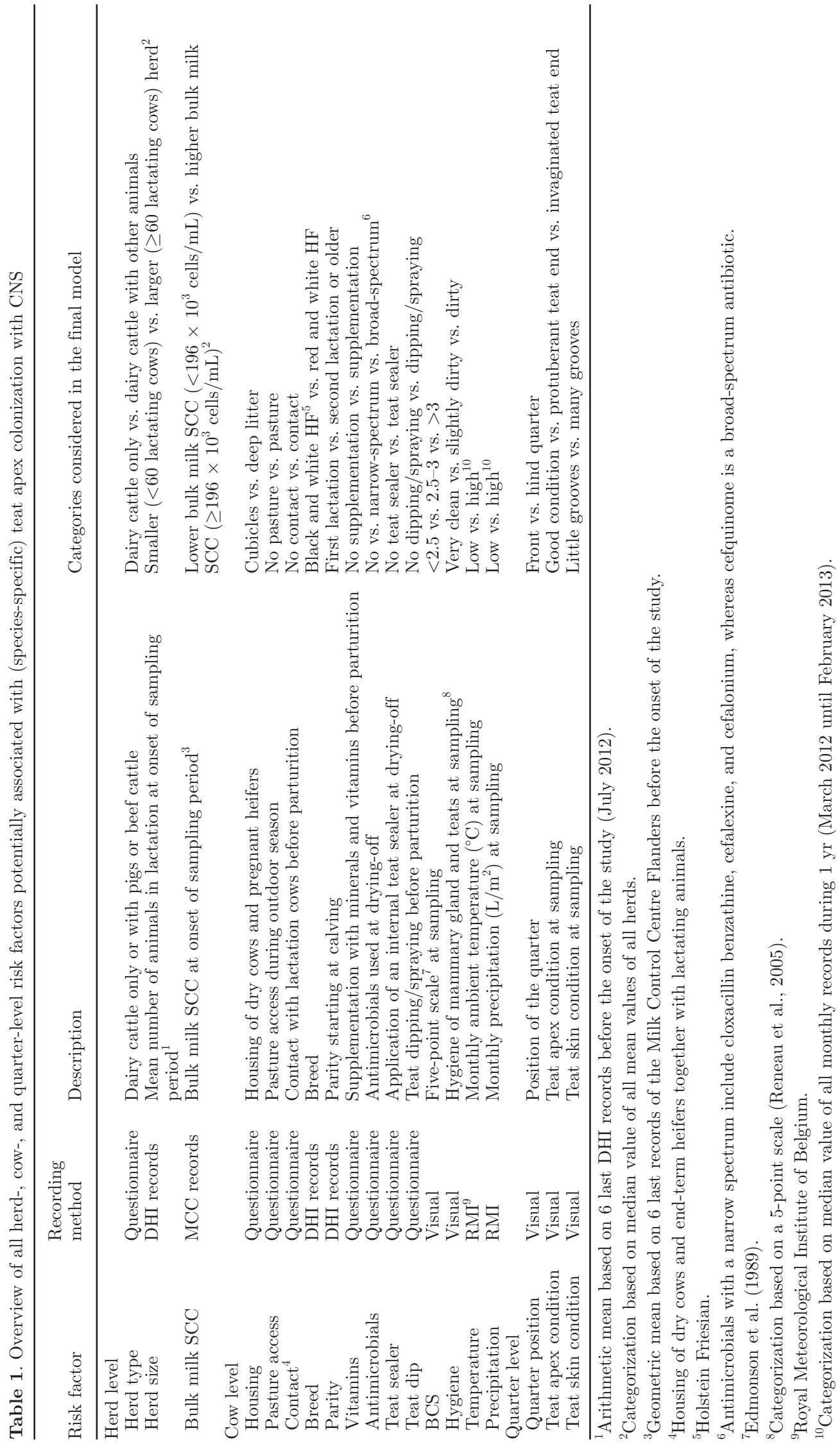




\section{Descriptive and Statistical Analyses}

Observations were checked for unlikely values before analyses were performed. Complete data were available from 596 teat apices from 96 dry cows and 53 end-term heifers.

Logistic multilevel regression models were fit using MLwiN 2.16 (Centre for Multilevel Modeling, University of Bristol, Bristol, UK) applying reweighted iterative generalized least squares and first-order penalized quasi-likelihood. As quarters were spatially clustered within cows and cows within herds, analysis were run with cow and herd as random effects.

Five different binary outcome variables at the quarter level were used: (1) teat apex colonized with CNS (whatever species) versus teat apex not colonized with CNS, and (2 to 5 ) teat apex colonized with one of the 4 most frequently isolated CNS species: (2) Staphylococcus devriesei, (3) S. chromogenes, (4) Staphylococcus haemolyticus, and (5) Staphylococcus equorum, versus teat apex not colonized with CNS or colonized with (an)other CNS species.

First, univariable associations were examined between the outcome variables and the independent factors (Table 1) with statistical significance assessed at $P$ $<0.15$. Second, Spearman rank correlation coefficients were calculated among the significant independent variables to avoid multicollinearity in the next steps. A correlation coefficient $\geq|0.6|$ among 2 factors led to the selection of 1 of the 2 variables for further analysis. In a third step, multivariable models were fit for all outcome variables using backward stepwise elimination. Statistical significance was assessed at $P<0.05$. Biological relevant interaction terms were tested between all remaining statistically significant factors and kept in the final multivariable model when significant $(P<0.05)$. A Bonferroni correction was applied to adjust for multiple comparisons. The observational-level standardized residuals were plotted against the observational-level predicted values to test the adequacy of all final models. In addition, the Hosmer-Lemeshow goodness-of-fit test and 2 residual log pseudo-likelihood statistics were assessed on the fixed effect models only (SAS 9.3, SAS Institute Inc., Cary, NC; Dohoo et al., 2009). The test was for none of the final models statistically significant indicating good fit of our models. Data are presented as odds ratios (OR) and $95 \%$ confidence intervals. The proportion of variation for the outcome variables at the herd, cow, and quarter level was estimated based on the null and final models by assuming that the variance at the quarter level was $\pi^{2} / 3$ (Dohoo et al., 2001) as described by Piepers et al. (2011).

\section{RESULTS}

\section{Descriptive Analyses}

The majority of teat apices $(87 \%, \mathrm{n}=540)$ yielded growth on mannitol salt agar and per plate 0 to 4 phenotypically different colony types were present. Different colony types sometimes appeared to belong to the same CNS species after tDNA-PCR or 16S rRNA gene sequencing, eventually resulting in 619 CNS isolates available for further analysis. Seventy-two percent (n $=448$ ) of all teat apices were colonized with CNS and harbored 1 up to 3 different CNS species. Twenty-four different CNS species were identified.

The overall most frequently isolated species was $S$. devriesei ( $19 \%$ of all teat apices colonized, $\mathrm{n}=120$ teat apices), followed by $S$. chromogenes $(17 \%, \mathrm{n}=107), S$. haemolyticus $(17 \%, \mathrm{n}=107)$, S. equorum $(13 \%, \mathrm{n}=81)$, Staphylococcus auricularis $(8 \%, \mathrm{n}=49)$, Staphylococcus sciuri $(7 \%, \mathrm{n}=41)$, Staphylococcus cohnii $(4 \%, \mathrm{n}=25)$, and Staphylococcus xylosus $(4 \%, \mathrm{n}=25$; Table 2). Isolates $(\mathrm{n}=390)$ other than CNS were phenotypically or genotypically (i.e., using tDNA-PCR or 16S rRNA gene sequencing) identified as Staphylococcus aureus ( $\mathrm{n}=$ 4), Arthrobacter spp. $(\mathrm{n}=1)$, Bacillus spp. $(\mathrm{n}=307)$, Jeotgalicoccus spp. $(\mathrm{n}=28)$, other gram-positive cocci such as Aerococcus spp. $(\mathrm{n}=12)$, Enterococcus spp. (n $=1)$, or Streptococcus spp. $(\mathrm{n}=5)$, gram-negative bacteria such as Pseudomonas spp. $(\mathrm{n}=16)$, Psychrobacter spp. $(\mathrm{n}=4)$ or other $(\mathrm{n}=7)$, and fungi $(\mathrm{n}=5)$.

On each herd, between 6 (herd 12) and 12 (herd 7) different CNS species were isolated from the teat apices. Staphylococcus chromogenes was the sole species colonizing teat apices in all 13 herds whereas $S$. devriesei, S. haemolyticus, and S. auricularis, were colonizing teat apices on all farms except one. Staphylococcus equorum, S. xylosus, S. sciuri, and S. cohnii could not be isolated from teat apices in 3, 4, 5, and 6 herds, respectively (Table 2, Figure 1). Species other than the aforementioned ones were only found in a minority of herds (Table 2).

The majority of the dry cows and pregnant heifers $(95 \%, \mathrm{n}=98$ out of 103 dry cows and $94 \%, \mathrm{n}=50$ out of 53 heifers, respectively) had at least one teat apex colonized with CNS. Seventy-four percent $(\mathrm{n}=$ 156) of all teat apices of the end-term heifers ( $\mathrm{n}=$ 212) harbored CNS, whereas $71 \%(\mathrm{n}=292)$ out of 412 teat apices of the dry cows were colonized with CNS. Teat apices of the pregnant heifers were mainly colonized by $S$. chromogenes ( $55 \%$ heifers, $\mathrm{n}=29$ out of 53 heifers and $21 \%$ teat apices, $\mathrm{n}=45$ out of 212 teat apices), followed by S. haemolyticus ( $42 \%$ heifers, 


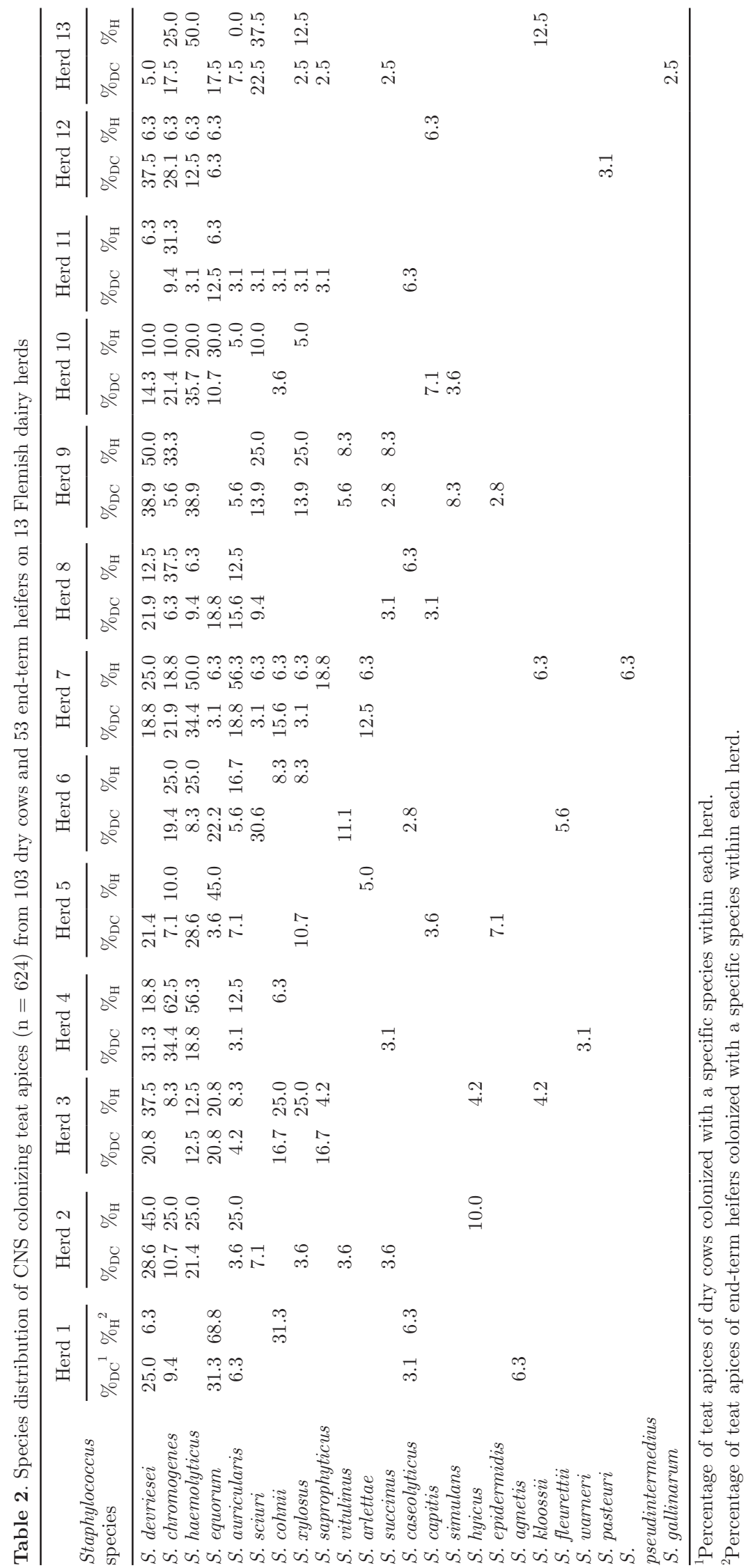




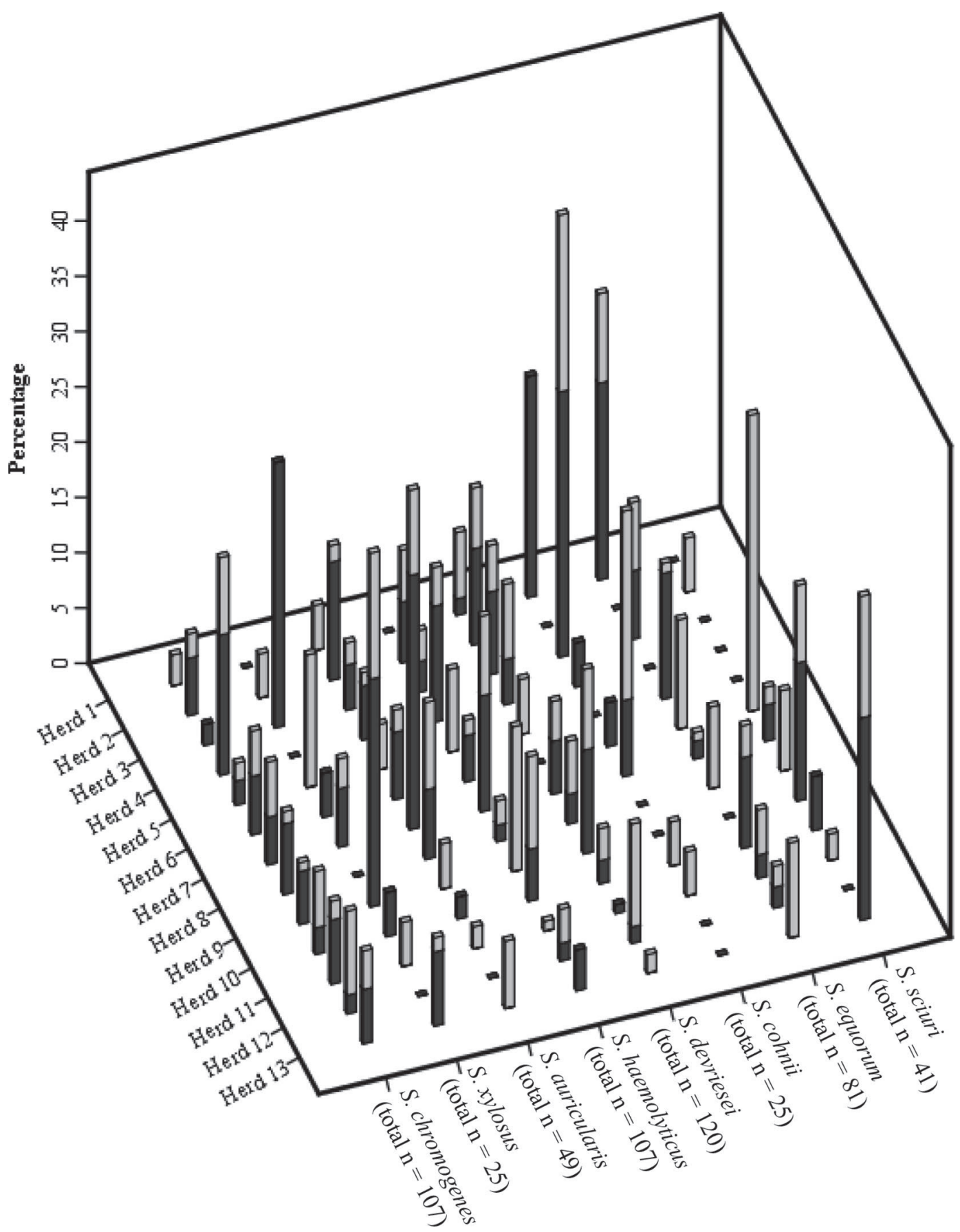

Figure 1. Distribution of CNS species on teat apices in 13 Flemish dairy herds in accordance with the proportion of teat apices from endterm heifers (black) and dry dairy cows (gray) respectively, per herd, colonized with a certain species relative to the total number of isolates over all herds per species.

$\mathrm{n}=22$ and $18 \%$ teat apices, $\mathrm{n}=38)$, S. devriesei $(40 \%$ heifers, $\mathrm{n}=21$ and $18 \%$ teat apices, $\mathrm{n}=38$ ), and $S$. equorum $(32 \%$ heifers, $\mathrm{n}=17$ and $16 \%$ teat apices, $\mathrm{n}=34)$. Staphylococcus epidermidis, Staphylococcus fleurettii, Staphylococcus gallinarum, Staphylococcus pasteuri, Staphylococcus simulans, and Staphylococcus warneri were not observed on teat apices from these young animals. Staphylococcus devriesei was the most frequently isolated species from the teat apices of the dry cows (44\% dry cows, $n=45$ out of 103 dry cows and $19 \%$ teat apices, $\mathrm{n}=82$ out of 412 teat apices), but the dominance of one species was less pronounced 
as observed for the heifers as other species were also often identified (S. haemolyticus: $39 \%$ dry cows, $\mathrm{n}=40$ and $17 \%$ teat apices, $\mathrm{n}=69, S$. chromogenes: $38 \%$ dry cows, $\mathrm{n}=39$ and $15 \%$ teat apices, $\mathrm{n}=62$, S. equorum: $28 \%$ dry cows, $\mathrm{n}=29$ and $11 \%$ teat apices, $\mathrm{n}=47$ ). Three species recovered from the heifers, Staphylococcus hyicus, Staphylococcus kloossii, and Staphylococcus pseudintermedius, could not be isolated from the teat apices of the dry cows.

\section{Risk Factors}

A first reduction based on unconditional associations revealed 4, 7, 6, 4, and 5 herd-, cow-, and quarter-level factors to be associated with TAC with CNS, S. devriesei, S. chromogenes, S. haemolyticus, and S. equorum, respectively (Table 3 ). No significant associations were identified for bulk milk SCC, housing, teat dip, BCS, and quarter position. Strong correlations between 2 or more factors were not observed. The final multilevel, multivariable logistic regression models are shown in Table 4.

Teat apices of red and white HF dry cows and pregnant heifers were more likely to be colonized with Staphylococcus devriesei $(\mathrm{OR}=2.22 ; 95 \%$ CI: $1.02-4.84)$ as opposed to teat apices from black and white HF. The application of an internal teat sealer significantly decreased the odds of being colonized with $S$. devriesei $(\mathrm{OR}=0.45 ; 95 \%$ CI: 0.21-0.95). Dirty teat apices were significantly more likely to be colonized with CNS in general $(\mathrm{OR}=2.91 ; 95 \% \mathrm{CI}: 1.47-5.77)$ and $S$. equorum in particular $(\mathrm{OR}=5.24 ; 95 \%$ CI: $1.87-14.66)$ than very clean teat apices. Slightly dirty teat apices had higher odds of being colonized with $S$. chromogenes (OR $=2.39 ; 95 \%$ CI: $1.30-4.40)$ as opposed to very clean teat apices. A higher ambient temperature significantly increased the odds of being colonized with $S$. devriesei $(\mathrm{OR}=6.63 ; 95 \%$ CI: $1.37-32.13)$ or $S$. haemolyticus (OR $=10.89 ; 95 \%$ CI: $1.27-93.52$ ), whereas the opposite was true for $S$. equorum $(\mathrm{OR}=0.30 ; 95 \%$ CI: $0.12-0.76)$ with the association even being more pronounced in case of low precipitation than in case of high precipitation (significant interaction term, see Figure 2). Teat apex colonization with Staphylococcus chromogenes was not associated with ambient temperature. Teat apices swabbed in months with high precipitation were less likely to be colonized with $\mathrm{CNS}$ in general $(\mathrm{OR}=0.45$; 95\% CI: $0.24-0.84)$, and with $S$. devriesei (OR $=0.35$; 95\% CI: 0.14-0.86), S. chromogenes (OR $=0.44 ; 95 \%$ CI: $0.21,0.94$ ), and $S$. haemolyticus (OR $=0.23 ; 95 \%$ CI: $0.08-0.67)$ in particular than teat apices swabbed in months with low precipitation. For S. equorum, the latter was only true in case of low ambient temperature and when no Bonferroni correction was applied (OR
$=0.21 ; 95 \%$ CI: 0.05-0.93; Table 4, Figure 2). In case of high ambient temperatures, teat apices swabbed in months with high precipitation were even more likely to be colonized with $S$. equorum than teat apices swabbed in months with low precipitation (Figure 2).

The highest variability was observed at the quarter level for all dependent variables. For the outcome variable Staphylococcus chromogenes TAC, the variation at the cow level in the null model was much more pronounced as opposed to the herd level, whereas this discrepancy was less pronounced for $S$. haemolyticus or $S$. devriesei and even absent for $S$. equorum (Table $5)$. For the latter species, the variation occurred in an almost equal amount at the cow and herd level.

\section{DISCUSSION}

This is the first large species-specific observational study that describes the prevalence and distribution of CNS colonizing teat apices from dry cows and endterm heifers and simultaneously identifies risk factors for TAC before calving at different levels of the data hierarchy. A sufficient number of herds, reflecting different management strategies, and the use of molecular speciation allowed us to precisely picture the speciesspecific CNS distribution on the teat apices. Similar to what was reported in lactating cows (Braem et al., 2013; De Visscher et al., 2014), the species distribution strongly varied among the different herds (Figure 1). None of the species was found on all farms except for S. chromogenes, which corresponds well with an earlier study reporting a herd-level prevalence of S. chromogenes colonized heifers of at least 10\% (De Vliegher et al., 2003). The prevalence of teat apices colonized with CNS as a group and with $S$. chromogenes in particular was higher than those observed in previous studies focusing on prepartum TAC with CNS as a group (Piepers et al., 2011) and S. chromogenes (De Vliegher et al., 2003), respectively. These differences might partially be explained by using a more suitable and appropriate medium in our study (De Visscher et al., 2013).

A lower percentage of teat apices was colonized with CNS in our previous work (De Visscher et al., 2014) than in the current study in which only teat apices before calving were swabbed. Routinely cleaning of the teats before cluster attachment, a flushing effect of the milking process (De Visscher et al., 2014), and the application of postmilking teat disinfection (Piessens et al., 2012; Quirk et al., 2012) may at least partly explain this discrepancy. Further, a higher number of species and some remarkable diversity in species distribution were found in our prepartum study compared with the studies concerning lactating cows (Braem et al., 2013; De Visscher et al., 2014). Staphylococcus devriesei, the 


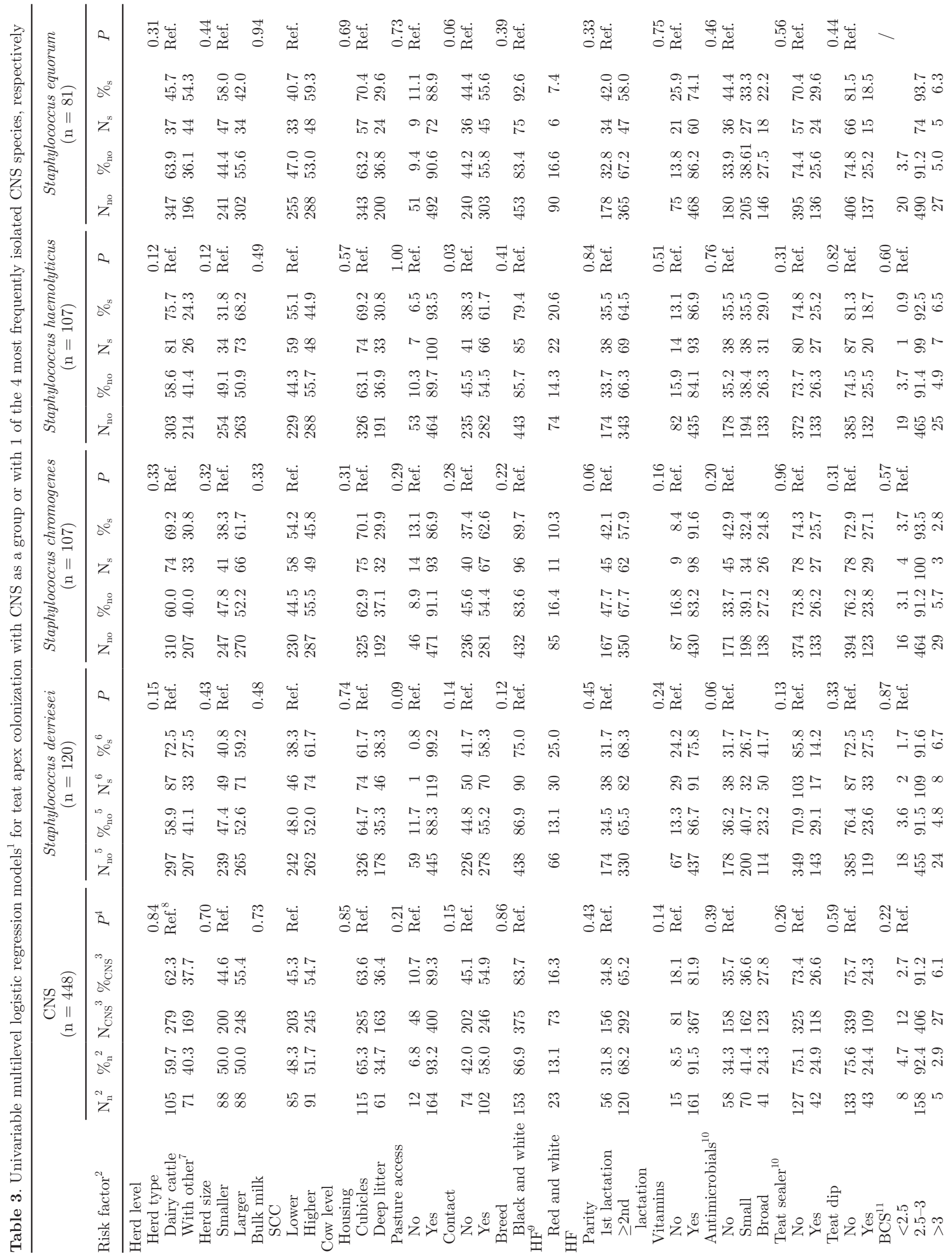




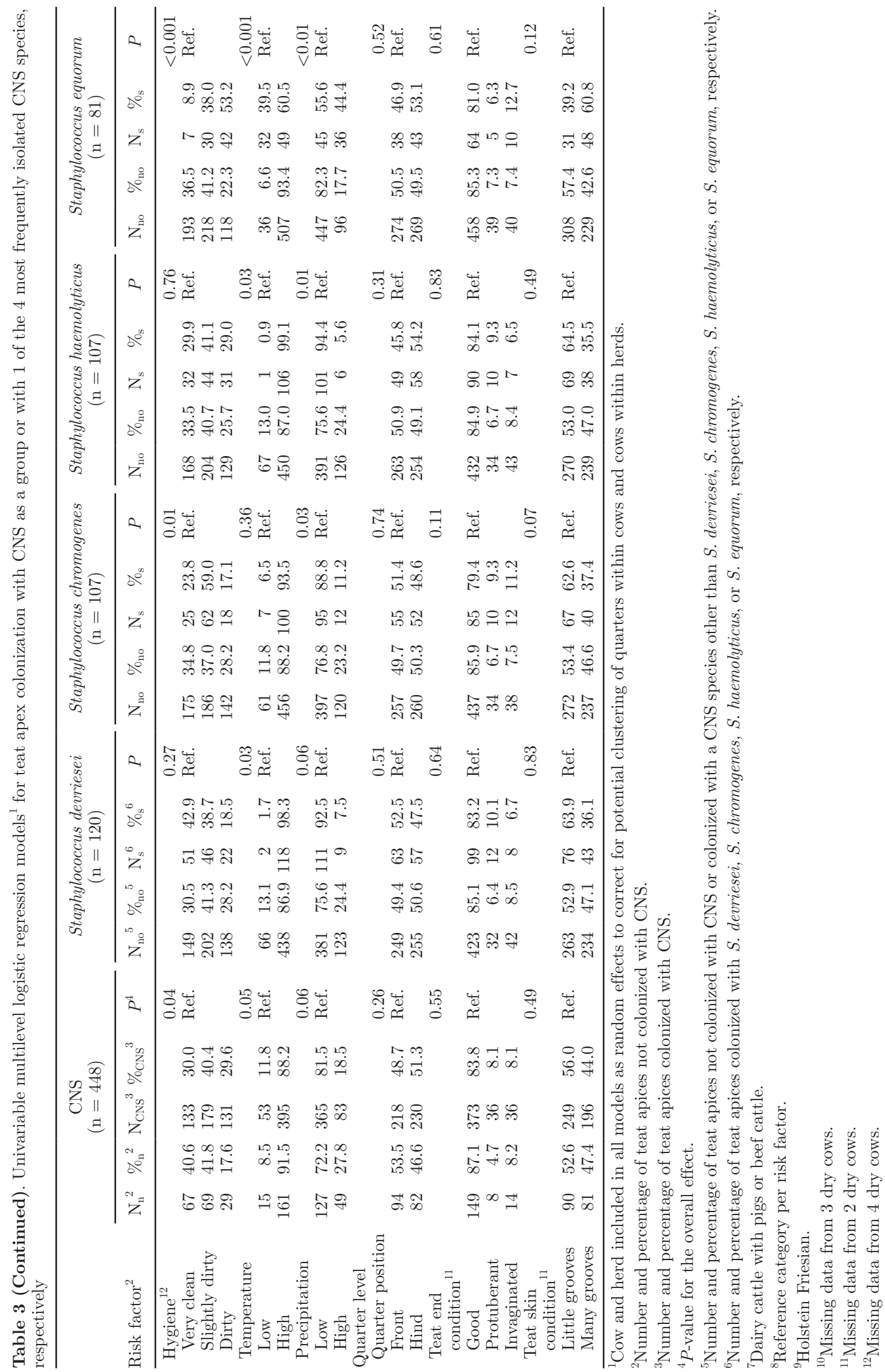




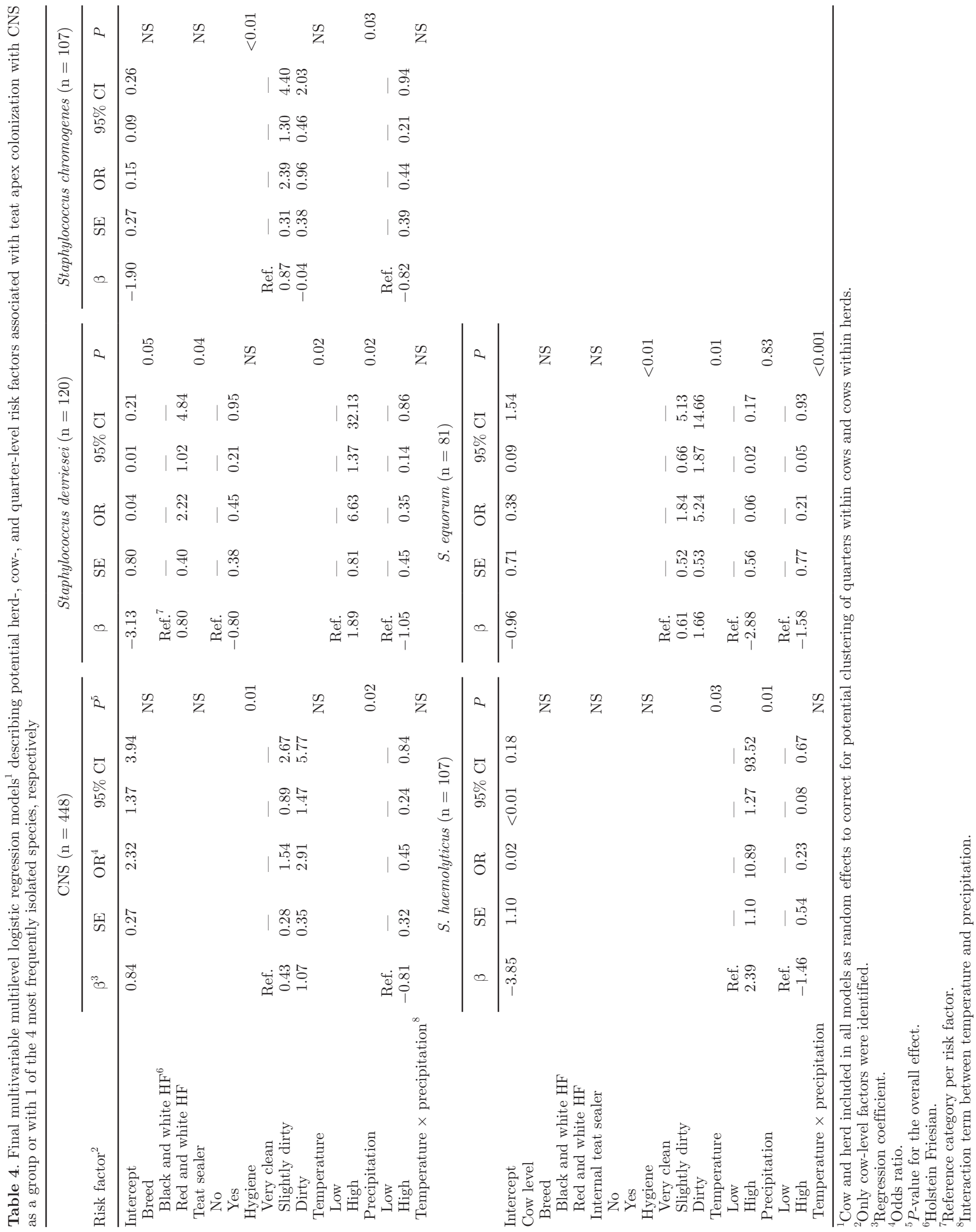


predominant species in the current study, was only rarely isolated in one (Braem et al., 2013) and even absent in another study (De Visscher et al., 2014), both focusing on TAC in lactating dairy cows. Although less pronounced as for $S$. devriesei, the same was true for S. auricularis (Braem et al., 2013; De Visscher et al., 2014). In turn, S. cohnii (Braem et al., 2013; De Visscher et al., 2014), Staphylococcus saprophyticus, S. simulans (Braem et al., 2013), S. xylosus (Taponen et al., 2008), and S. fleurettii (De Visscher et al., 2014) were less commonly isolated from teat apices from nonlactating cows and heifers as opposed to teat apices from lactating dairy cows. The differences between lactating and nonlactating animals are less consistent for $S$. chromogenes, the second most frequently isolated species. Staphylococcus chromogenes could not be or could hardly be isolated from teat apices from lactating dairy cows in some studies (Braem et al., 2013; De Visscher et al., 2014), but was often isolated from bovine teat skin in some other single-dairy-herd studies (White et al., 1989; Taponen et al., 2008). Staphylococcus haemolyticus, S. equorum (Braem et al., 2013; De Visscher et al., 2014; Vanderhaeghen et al., 2015), and to a lesser extent also S. sciuri (Braem et al., 2013: De Visscher et al., 2014) were frequently isolated species from teat apices from both lactating dairy cows and nonlactating cows and heifers. Again, our findings suggest that herds have various CNS microbiota colonizing different habitats implying the potential role of management strategies. Although we have included herd-level factors

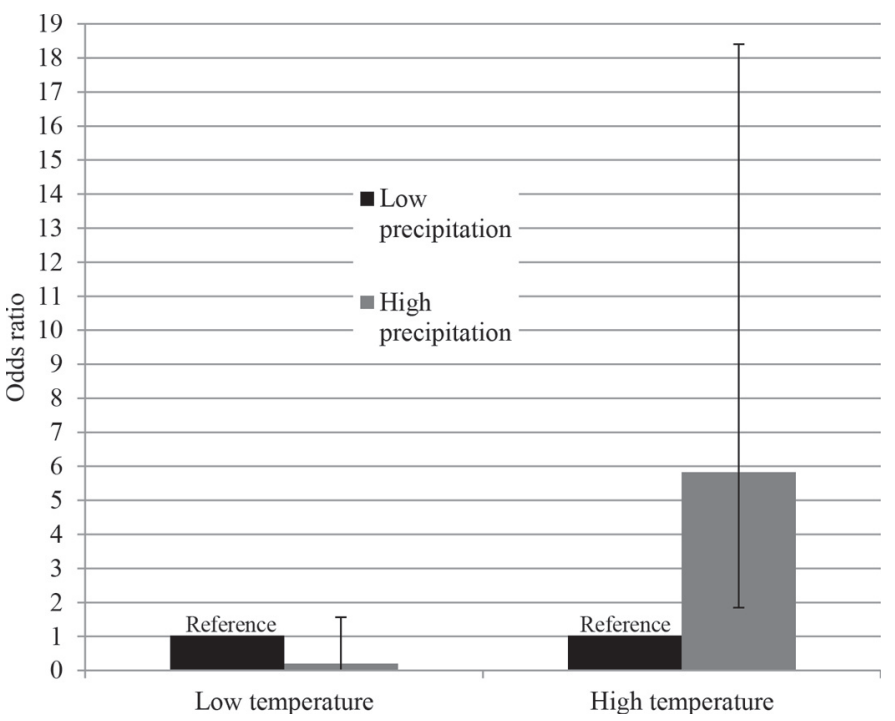

Figure 2. Interaction term between temperature and precipitation visualized using odds ratios and $95 \%$ confidence intervals for teat apices colonized with Staphylococcus equorum versus not colonized or colonized with (an)other coagulase-negative Staphylococcus species (as shown in Table 4). 
in the current study, the number of herds was too small to identify important ones. Other studies, specifically designed for analyzing herd-level variables, are needed.

Teat apices of red and white HF as opposed to teat apices of black and white HF dry cows and pregnant heifers were more likely to be colonized with Staphylococcus devriesei. Also, the application of an internal teat sealer, a management tool useful in preventing environmental pathogens invading quarters during the dry period (Huxley et al., 2002), significantly decreased the odds of being colonized with $S$. devriesei in this study. No well-defined interpretation can explain these observed associations, yet they merit further study. Staphylococcus devriesei was also significantly more present on teat apices in months with low precipitation and high ambient temperatures comparable to what was observed for S. haemolyticus. Because hygiene did not influence TAC with Staphylococcus devriesei or with $S$. haemolyticus in the current study, an environmental nature of $S$. devriesei and $S$. haemolyticus could be questioned as previously reported for $S$. haemolyticus by Leroy et al. (2015). Strain typing is necessary to come to better conclusions. Because staphylococci prefer a higher temperature to grow (Prescott et al., 2002) and dryness might cause imperceptible teat end lesions, forming a good matrix for expanding the present CNS microbiota, warmth, and low precipitation could provide $S$. devriesei and $S$. haemolyticus with good growth conditions.

On the other hand, TAC with Staphylococcus equorum was significantly associated with hygiene, with dirty teat apices being more colonized as opposed to very clean teat apices. In addition, teat apices were more likely to be colonized with $S$. equorum when swabbed under humid conditions in combination with a higher ambient temperature. The latter climatic conditions could support the bacterial load from the environment and thus could increase the exposure of teat apices to S. equorum (Smith et al., 1985). Earlier studies also observed a more pronounced presence of $S$. equorum in extramammary habitats (Piessens et al., 2011; De Visscher et al., 2014) as opposed to milk (Supré et al., 2011; Piessens et al., 2011; Fry et al., 2014) and our current findings seem to confirm the environmental nature of S. equorum.

Staphylococcus chromogenes was rarely isolated from the bovine environment (Piessens et al., 2011), but was predominantly present in bovine IMI (Piessens et al., 2011; Supré et al., 2011; Fry et al., 2014). An earlier study (De Vliegher et al., 2003) and the current prepartum study observed $S$. chromogenes TAC in all included herds. The latter observations all indicate a host-adapted nature of $S$. chromogenes. On the other hand, teat apices from lactating dairy cows and heifers were hardly colonized with $S$. chromogenes (Taponen et al., 2008; Braem et al., 2013; De Visscher et al., 2014). This can partly be explained by a smaller number of included herds, different genotypic methods, or both, yet needs further study.

Most of variation of the outcome variables in the null models resided at the quarter level as reported before for CNS IMI (Piepers et al., 2011; Passchyn et al., 2014). As no quarter-level factors were identified and the variation explained in the final models was low, as seen before (Piepers et al., 2011; Verbeke et al., 2012; Passchyn et al., 2014), factors others than the studied ones play a key role in explaining the likelihood of colonization (or infection). For example, focusing on teat dimensions might be useful in improving udder health (Zwertvaegher et al., 2013) and a potential pathway is diversity among cows and heifers due to their distinct genetic background (Detilleux, 2009; Verbeke et al., 2012). Differences in susceptibility for CNS IMI among cows and quarters could also rely on differences in immune status (Piepers et al., 2009), which is also partially genetically determined. Still, calculation of the variance components for binary outcome variables is not as straightforward as it is for continuous outcomes (Dohoo et al., 2009), making comparisons with that level not appropriate. Still, we hypothesize that factors at the quarter level rather than at the cow and herd level play a more important role for S. chromogenes TAC than for TAC with the other 3 species. For TAC with $S$. chromogenes, more variation was present between cows than between herds when compared with the other species, which is most likely related to the fact that $S$. chromogenes was the sole species colonizing teat apices in all included herds. Regarding the proportion of variation being present at the herd or cow level, analogous patterns could be observed for $S$. devriesei and S. haemolyticus. Remarkably, for TAC with $S$. equorum an almost equal amount of the total variation occurred at the herd and cow level despite being an environmental species.

\section{CONCLUSIONS}

Staphylococcus devriesei, S. chromogenes, S. haemolyticus, and $S$. equorum were the predominant species colonizing teat apices from dry dairy cows and end-term heifers before calving. Staphylococcus chromogenes was present on teat apices in all herds whereas large herd differences were observed for other species. Diverse factors explaining CNS species-specific TAC, yet mostly related to humidity, ambient temperature, and hygiene, substantiate differences in epidemiological behavior and ecology between species. An environmental nature for $S$. equorum is suggested, whereas $S$. haemolyticus 
and $S$. devriesei seem to act as cow-adapted bacteria, as $S$. chromogenes does.

\section{ACKNOWLEDGMENTS}

This study was funded by the Agency for Innovation by Science and Technology, Flanders, Belgium (IWTVlaanderen, grant no. 111588). The authors thank Lars Hulpio (Department of Reproduction, Obstetrics, and Herd Health, Faculty of Veterinary Medicine, Ghent University, Merelbeke, Belgium) for his technical assistance.

\section{REFERENCES}

Braem, G., S. De Vliegher, B. Verbist, M. Heyndrickx, F. Leroy, and L. De Vuyst. 2012. Culture-independent exploration of the teat apex microbiota of dairy cows reveals a wide bacterial species diversity. Vet. Microbiol. 157:383-390.

Braem, G., S. De Vliegher, B. Verbist, V. Piessens, E. Van Coillie L. De Vuyst, and F. Leroy. 2013. Unraveling the microbiota of teat apices of clinically healthy lactating dairy cows, with special emphasis on coagulase-negative staphylococci. J. Dairy Sci. 96:1499-1510.

De Visscher, A., F. Haesebrouck, S. Piepers, W. Vanderhaeghen, K. Supré, F. Leroy, E. Van Coillie, and S. De Vliegher. 2013. Assessment of the suitability of mannitol salt agar for growing bovineassociated coagulase-negative staphylococci and its use under field conditions. Res. Vet. Sci. 95:347-351.

De Visscher, A., K. Supré, F. Haesebrouck, R. N. Zadoks, V. Piessens, E. Van Coillie, S. Piepers, and S. De Vliegher. 2014. Further evidence for the existence of environmental and host-associated species of coagulase-negative staphylococci in dairy cattle. Vet. Microbiol. 172:466-474. http://dx.doi.org/10.1016/j.vetmic.2014.06.011.

De Vliegher, S., H. Laevens, L. A. Devriese, G. Opsomer, J. L. M. Leroy, H. W. Barkema, and A. de Kruif. 2003. Prepartum teat apex colonization with Staphylococcus chromogenes in dairy heifers is associated with low somatic cell count in early lactation. Vet. Microbiol. 92:245-252.

Detilleux, J. C. 2009. Genetic factors affecting susceptibility to udder pathogens. Vet. Microbiol. 134:157-164.

Dohoo, I., W. Martin, and H. Stryhn. 2009. Mixed models for discrete data. Pages 579-606 in Veterinary Epidemiologic Research. 2nd ed. I. Dohoo, W. Martin, and H. Stryhn, ed. AVC Inc., Charlottetown, Canada.

Dohoo, I. R., E. Tillard, H. Stryhn, and B. Faye. 2001. The use of multilevel models to evaluate sources of variation in reproductive performance in dairy cattle in Reunion Island. Prev. Vet. Med. 50:127-144.

Edmonson, A. J., I. J. Lean, L. D. Weaver, T. Farver, and G. Webster. 1989. A body condition scoring chart for Holstein dairy cows. J. Dairy Sci. 72:68-78.

Fry, P. R., J. R. Middleton, S. Dufour, J. Perry, D. Scholl, and I. Dohoo. 2014. Association of coagulase-negative staphylococcal species, mammary quarter milk somatic cell count, and persistence of intramammary infection in dairy cattle. J. Dairy Sci. 97:4876-4885.

Huxley, J. N., M. J. Green, L. E. Green, and A. J. Bradley. 2002. Evaluation of the efficacy of an internal teat sealer during the dry period. J. Dairy Sci. 85:551-561.

Leroy, F., E. Van Coillie, G. Braem, V. Piessens, B. Verbist, L. De Vuyst, and S. De Vliegher. 2015. Short communication: Subtyping of Staphylococcus haemolyticus isolates from milk and corresponding teat apices to verify the potential teat-skin origin of intramammary infections in dairy cows. J. Dairy Sci. 98:7893-7898.

Passchyn, P., S. Piepers, and S. De Vliegher. 2014. Pathogen groupspecific risk factors for intramammary infection in treated and untreated dairy heifers participating in a prepartum antimicrobial treatment trial. J. Dairy Sci. 97:6260-6270.

Piepers, S., G. Opsomer, E. Meyer, K. Demeyere, H. W. Barkema, A. de Kruif, and S. De Vliegher. 2009. Heifer and quarter characteristics associated with periparturient blood and milk neutrophil apoptosis in healthy heifers and in heifers with subclinical mastitis. J. Dairy Sci. 92:4330-4339.

Piepers, S., K. Peeters, G. Opsomer, H. W. Barkema, K. Frankena, and S. De Vliegher. 2011. Pathogen group specific risk factors at herd, heifer and quarter levels for intramammary infections in early lactating dairy heifers. Prev. Vet. Med. 99:91-101.

Piessens, V., S. De Vliegher, B. Verbist, G. Braem, A. Van Nuffel, L. De Vuyst, M. Heyndrickx, and E. Van Coillie. 2012. Characterization of coagulase-negative Staphylococcus species from cows' milk and environment based on bap, icaA, and mecA genes and phenotypic susceptibility to antimicrobials and teat dips. J. Dairy Sci. 95:7027-7038.

Piessens, V., E. Van Coillie, B. Verbist, K. Supré, G. Braem, A. Van Nuffel, L. De Vuyst, M. Heyndrickx, and S. De Vliegher. 2011. Distribution of coagulase-negative Staphylococcus species from dairy cows' milk and environment differs between herds. J. Dairy Sci. 94:2933-2944

Prescott, L. M., J. P. Harley, and D. A. Klein. 2002. Microbial growth. The influence of environmental factors on growth. Pages 118-125 in Microbiology. 5th ed. L. M. Prescott, J. P. Harley, and D. A. Klein, ed. The McGraw-Hill Inc., New York, NY.

Quirk, T., L. K. Fox, D. D. Hancock, J. Capper, J. Wenz, and J. Park. 2012. Intramammary infections and teat canal colonization with coagulase-negative staphylococci after postmilking teat disinfection: Species-specific responses. J. Dairy Sci. 95:1906-1912.

Reneau, J. K., A. J. Seykora, B. J. Heins, M. I. Endres, R. J. Farnsworth, and R. F. Bey. 2005. Associations between hygiene scores and somatic cell scores in dairy cattle. J. Am. Vet. Med. Assoc. 227:1297-1301.

Smith, K. L., D. A. Todhunter, and P. S. Schoenberger. 1985. Environmental mastitis: Cause, prevalence and prevention. J. Dairy Sci. 68:1531-1553.

Supré, K., S. De Vliegher, O. C. Sampimon, R. N. Zadoks, M. Vaneechoutte, M. Baele, E. De Graef, S. Piepers, and F. Haesebrouck. 2009. Technical note: Use of transfer RNA-intergenic spacer PCR combined with capillary electrophoresis to identify coagulase-negative Staphylococcus species originating from bovine milk and teat apices. J. Dairy Sci. 92:3204-3210.

Supré, K., F. Haesebrouck, R. N. Zadoks, M. Vaneechoutte, S. Piepers, and S. De Vliegher. 2011. Some coagulase-negative Staphylococcus species affect udder health more than other. J. Dairy Sci. 94:23292340 .

Taponen, S., J. Björkroth, and S. Pyörälä. 2008. Coagulase-negative staphylococci isolated from bovine extramammary sites and intramammary infections in a single dairy herd. J. Dairy Res. 75:422429 .

Vanderhaeghen, W., S. Piepers, F. Leroy, E. Van Coillie, F. Haesebrouck, and S. De Vliegher. 2014. Invited review. Effect, persistence, and virulence of coagulase-negative Staphylococcus species associated with ruminant udder health. J. Dairy Sci. 97:5275-5293.

Vanderhaeghen, W., S. Piepers, F. Leroy, E. Van Coillie, F. Haesebrouck, and S. De Vliegher. 2015. Identification, typing, ecology and epidemiology of coagulase-negative staphylococci associated with ruminants. Vet. J. 203:44-51.

Verbeke, J., S. Piepers, L. Peelman, M. Van Poucke, and S. De Vliegher. 2012. Pathogen-group specific association between CXCR1 polymorphisms and subclinical mastitis in dairy heifers. J. Dairy Res. 79:341-351.

White, D. G., R. J. Harmon, J. E. S. Matos, and B. E. Langlois. 1989. Isolation and identification of coagulase-negative Staphylococcus species from bovine body sites and streak canals of nulliparous heifers. J. Dairy Sci. 72:1886-1892.

Zwertvaegher, I., S. De Vliegher, B. Verbist, A. Van Nuffel, J. Baert, and S. Van Weyenberg. 2013. Short communication: Associations between teat dimensions and milking-induced changes in teat dimensions and quarer milk somatic cell counts in dairy cows. J. Dairy Sci. 96:1075-1080. 